\title{
KESALAHAN PENULISAN KONJUNGTOR DALAM NOVEL GARIS WAKTU: SEBUAH PERJALANAN MENGHAPUS LUKA KARYA FIERSA BESARI
}

\author{
Rahmad Hidayat', Lalu Jaswadi Putera² \\ UPT MKU Universitas Mataram \\ asscouty456@gmail.com ${ }^{1}$, elputra.unram@gmail.com²
}

\section{INFO ARTIKEL}

Riwayat Artikel:

Diterima: 31-08-2017

Disetujui: 30-09-2017

\section{Kata Kunci:}

Kesalahan Penulisan Konjungtor

Novel Garis Waktu: Sebuah Perjalanan Menghapus Luka karya Fiersa Besari
\end{abstract}

\section{A. LATAR BELAKANG}

Kalimat majemuk adalah kalimat yang mengandung dua pola kalimat atau lebih (Keraf, 1987). Kalimat majemuk terbagi atas tiga jenis; kalimat majemuk setara, kalimat majemuk bertingkat, dan kalimat majemuk campuran. kalimat majemuk setara terdiri atas pola-pola kalimat yang berkedudukan sama tinggi, sedangkan kalimat majemuk bertingkat terdiri atas pola-pola kalimat yang tidak sederajat dan terdapat pola kalimat yang menduduki suatu fungsi dari pola lainnya, sementara kalimat majemuk campuran terdiri atas pola-pola kalimat yang dapat setara dan bertingkat. kalimat majemuk campuran hanya akan dapat terbentuk jika di dalam kalimat majemuk terdapat tiga pola kalimat (Keraf, 1987).
Struktur dasar kalimat minimal terdiri atas fungsi wajib berupa subjek dan predikat, serta secara opsional mengandung fungsi berupa objek, pelengkap, dan keterangan. Kehadiran dua buah kalimat sederhana atau lebih disambungkan dengan koordinator berupa konjungtor membentuk konstruksi yang lebih kompleks yang disebut dengan kalimat majemuk. Dengan demikian, syarat utama sebuah konstruksi dikatakan sebagai konstruksi yang majemuk adalah wajib hadirnya minimal dua buah klausa atau lebih yang memenuhi standar klausa dan dihubungkan oleh sebuah konjungtor atau kata sambung.

Sebagai sebuah konstruksi yang kompleks, kalimat majemuk menyiratkan beberapa persoalan di balik unsurunsur pembentuknya. Konjungtor sebagai penghubung antarklausa seringkali menjadi masalah dalam tulis- 
menulis. Pemakaian konjungtor yang berlebihan, penempatan konjungtor yang salah, serta tumpang-tindih antarsesama konjungtor sering terjadi.

Pemakaian konjungtor yang lewah menyebabkan lewahnya kandungan makna. Lewahnya penggunaan konjungtor karena penulis menggunakan dua konjungtor sekaligus dalam sebuah kalimat majemuk yang disusunnya, padahal kejadian semacam itu hanya dimungkinkan pada kasus konjungtor yang korelatif. Konjungtor korelatif pun sebenarnya masih dianggap sebagai satu-kesatuan karena sifatnya yang berkorelasi.

Kesalahan penempatan konjungtor menyebabkan kaburnya struktur fungsi kalimat yang dibentuk. Kesalahan penempatan konjungtor ini biasanya disebabkan oleh tertukarnya anggapan penulis terhadap konjungtor intrakalimat dengan konjungtor antarkalimat. Kedua jenis konjungtor ini sering dipertukarkan posisinya, utamanya konjungtor intrakalimat menempati posisi konjungtor antarkalimat. Hal tersebut membuat kalimat yang "seharusnya" majemuk menjadi kalimat sederhana yang struktur fungsinya tidak dimungkinkan karena terdapat konjungsi.

Tumpang-tindih antarkonjungtor menyebabkan kaburnya makna kalimat yang disusun. Tumpang-tindih ini sering terjadi pada konjungtor subordinatif bersyarat semacam jika yang dipasangkan dengan maka. Dalam tulisan ini, terdapat pula data dua konjungtor yang dipaksakan sehingga bertumpang-tindih.

Beberapa persoalan tersebut akan diperinci di bagian pembahasan dalam tulisan ini. Data kalimat majemuk diambil dari novel berjudul Garis Waktu: Sebuah Perjalanan Menghapus Luka karangan Fiersa Besari (2016). Pemilihan sumber data dari novel hanya untuk memudahkan pencarian contoh dalam satu sumber. Kenyataan semacam ini juga banyak ditemukan di sumber yang lain seperti tulisan akademik dan tulisan dinas resmi. Data kalimat majemuk baik setara maupun bertingkat diambil berdasarkan kebutuhan sesuai dengan poin persoalan yakni (1) kelewahan penggunaan konjungtor, (2) kesalahan penempatan konjungtor, dan (3) tumpangtindih antarkonjungtor.

Tulisan ini dimaksudkan untuk membuka pikiran penulis dalam bahasa Indonesia untuk lebih memperhatikan penggunaan konjungtor sesuai dengan kaidah yang berlaku. Hal ini penting karena penulis pemula terkadang tidak sadar telah menempatkan dan menggunakan konjungtor tidak pada posisi yang seharusnya.

\section{B. METODE PENELITIAN}

Penelitian ini memanfaatkan data yang terdapat dalam novel Garis Waktu: Sebuah Perjalanan Menghapus Luka karya Fiersa Besari. Data yang dikumpulkan berupa konjungtor yang terdapat dalam novel. Selain konjungtor, kalimat yang menjadi konteks atau tempat beradanya konjungtor tersebut juga dikumpulkan. Panjang kalimat yang diambil disesuaikan dengan keumuman konstruksi kalimat majemuk dalam bahasa Indonesia.

Setelah konjungtor terkumpul bersama kalimat yang menjadi konteksnya. Konjungtor tersebut dikelompokkan sesuai dengan bentuk kesalahan yang sesuai dengan kenyataannya. Penentuan kesalahan didasarkan pada kaidah bahasa Indonesia yang terdapat dalam Tata Bahasa Baku Bahasa Indonesia karangan Alwi, dkk (2003).

Dalam pada itu, tidak semua data konjungtor yang terdapat dalam novel ditampilkan dalam penelitian ini. Data konjungtor yang diambil dan ditampilkan dalam penelitian ini bersifat mewakili data yang lain. Hal ini dilakukan demi kefokusan pembahasan. Selain itu, hal tersebut dilakukan untuk menghindari banyaknya data yang ditampilkan berulang-ulang.

\section{HASIL DAN PEMBAHASAN}

Dalam tulisan ini kalimat majemuk dibedakan menjadi dua, yakni kalimat majemuk setara dan kalimat majemuk bertingkat. Berdasarkan perbedaan ini pula, konjungtor yang menghubungkan klausa dalam rangka membentuk kalimat majemuk dibedakan menjadi dua, yakni konjungtor yang menyatakan hubungan koordinasi dalam kalimat majemuk setara dan konjungtor yang menyatakan hubungan subordinasi dalam kalimat majemuk bertingkat. Konjungtor pada kalimat majemuk setara berupa dan, atau, serta, tetapi, lalu, kemudian, padahal, sedangkan, dan semacamnya sedangkan konjungtor pada kalimat majemuk bertingkat berupa bahwa, setelah, jika, andaikan, agar, meskipun, karena, sehingga, dengan, dan semacamnya.

Hubungan koordinasi dalam kalimat majemuk setara berkonsekuensi klausa pembangun maupun konjungtor masing-masing berdiri sendiri dan tidak menjadi bagian klausa yang lain. Misalnya, konstruksi Dosen mengajar mahasiswa dengan baik dan mahasiswa menyimak perkataan dosen dengan penuh konsentrasi merupakan kalimat majemuk setara dengan unsur pembentuk berupa konjungtor dan dan dua buah klausa, masing-masing dosen mengajar mahasiswa dengan baik dan mahasiswa menyimak perkataan dosen dengan penuh konsentrasi.

Berbeda dengan hubungan koordinasi dalam kalimat majemuk setara, hubungan subordinasi dalam kalimat majemuk bertingkat berkonsekuensi konjungtor menjadi bagian dari klausa dan klausa tersebut menjadi klausa yang tidak sama kedudukannya dengan klausa yang lain. Misalnya, konstruksi Dosen memberi arahan sebelum perkuliahan berakhir. Konstruksi tersebut terdiri atas klausa perkuliahan berakhir dan dosen memberi arahan ditambah dengan konjungtor sebelum. Dalam konstruksi majemuk bertingkat tersebut, konjungtor sebelum menjadi bagian tak terpisah dari klausa perkuliahan berakhir. Hal 
ini dapat dibuktikan dengan memerikan fungsi sintaksis kalimat majemuk tersebut secara keseluruhan.

Fungsi sintaksis kalimat tersebut yakni dosen sebagai subjek, memberi sebagai predikat, arahan sebagai objek, dan sebelum perkuliahan berakhir sebagai keterangan. Kebersamaan konjungtor dan salah satu klausa menempati sebuah fungsi yang sama membuktikan bahwa konjungtor pada kalimat majemuk bertingkat merupakan bagian dari klausa yang bersangkutan. Dalam hal ini, klausa tersebut disebut dengan klausa bawahan. Sebaliknya, klausa yang lain disebut sebagai klausa inti. Kenyataan ini membuat posisi klausa dapat dipertukarkan tanpa mengganggu kegramatikalan kalimat menjadi Sebelum perkuliahan berakhir, dosen memberi arahan. Hal ini berbeda dengan konstruksi kalimat majemuk setara di atas yang tidak dapat diubah posisinya menjadi ${ }^{*}$ Dan mahasiswa menyimak perkataan dosen dengan penuh konsentrasi, dosen mengajar mahasiswa dengan baik.

Pengantar awal pada bagian ini dihajatkan untuk membantu penjelasan pada bagian berikutnya. Selain pembahasan mengenai perbedaan konjungtor dalam kalimat majemuk setara dan bertingkat, perlu dipahami juga beberapa pembagian konjungtor berdasarkan sudut pandang yang lain.

Konjungtor berdasarkan posisinya dibedakan menjadi konjungtor intrakalimat dan konjungtor antarkalimat. Konjungtor intrakalimat meliputi seluruh konjungtor yang menghubungkan dua klausa pada kalimat majemuk setara dan bertingkat sedangkan konjungtor antarkalimat menghubungkan dua kalimat yang masing-masing kalimatnya telah dipisahkan oleh tanda titik.

Konjungtor berdasarkan perilaku sintaksisnya dibagi menjadi tiga yakni konjungtor koordinatif, subordinatif, dan konjungtor korelatif (lihat Alwi dkk., 2003: 297). Sifat koordinatif dan subordinatif telah dijelaskan di atas sedangkan sifat korelatif berarti ada dua bentuk konjungtor yang berkorelasi yang merupakan satukesatuan. Konjungtor korelatif ini seperti baik-maupun, bukan-melainkan, tidak-tetapi, demikian-hingga, dan semacamnya.

Patut juga menjadi catatan di sini mengenai struktur fungsi. Fungsi dalam kalimat merupakan ruang kosong yang diisi oleh konstituen tertentu. Fungsi itu seperti subjek (S), predikat (P), objek (O), pelengkap (Pel.), dan keterangan (K). Struktur fungsi yang dimungkinkan dalam kalimat sederhana (lawan dari kalimat majemuk) maksimal terdiri atas S + P + O + Pel. + K (lihat Alwi, dkk., 2003: 320-322; Ramlan, 2005: 80-87; Sugihastuti dan Saudah, 2016: 234-236). Dengan demikian, struktur fungsi maksimal yang dimungkinkan dalam kalimat majemuk adalah $\mathrm{S}+\mathrm{P}+\mathrm{O}+$ Pel. $+\mathrm{K}+$ Konjungtor $+\mathrm{S}+\mathrm{P}+$ $\mathrm{O}+$ Pel. + K. Kelebihan fungsi dari jumlah maksimal yang dimungkinkan merupakan kesalahan kalimat.

\section{Kelewahan Penggunaan Konjungtor}

Kelewahan penggunaan konjungtor yang dimaksud dalam tulisan ini adalah penggunaan dua konjungtor dalam sebuah kalimat majemuk (kecuali dan kemudian dan dan malah, lihat Alwi dkk., 2003: 395). Kenyataan ini mengaburkan fungsi konjungtor itu sendiri dalam bahasa Indonesia, yakni sebagai penghubung antarkalimat dalam kalimat majemuk. Data yang menunjukkan perihal tersebut adalah sebagai berikut.

(1) maka, izinkanlah aku menulis untukmu, tentangmu, meski aku tidak tahu apakah surat ini akan tiba di sisi ranjangmu... (GW, hal. 8)

Konjungtor maka dan meski pada data (1) masingmasing merupakan konjungtor dalam kalimat majemuk bertingkat yang menyatakan hubungan subordinatif. Data tersebut mengandung dua kesalahan sekaligus, yakni kesalahan penempatan konjungtor sebagaimana yang akan dibahas pada poin kedua dan kelewahan penggunaan konjungtor.

Kelewahan ditunjukkan dengan perbedaan makna maka dan meski yang jauh dan tidak saling berhubungan satu sama lain. Konjungtor meski yang menyatakan hubungan konsesif dikacaukan dengan maka sebagai konjungtor yang bermakna hasil. Penggabungan kedua konjungtor tersebut dalam satu posisi berurutan merupakan kelewahan dalam berbahasa karena tumpangtindih makna yang dikandungnya.

Kelewahan ini berdampak pula pada kekacauan konstruksi kalimat. Sebagaimana gambaran di bagian pengantar, konstruksi kalimat majemuk dengan konjungtor yang subordinatif dapat dipertukarkan posisi anak kalimat dengan induk kalimatnya. Tanpa pengubahan posisi pun sebenarnya, kalimat pada data (1) sudah merupakan kalimat majemuk yang tidak berterima. Pengubahan posisi akan lebih menunjukkan kekeliruan yang dimaksud. Perubahan konstruksi kalimat pada data (1) menjadi *meski aku tidak tahu apakah surat ini akan tiba di sisi ranjangmu maka, izinkanlah aku menulis untukmu, tentangmu. Selain itu, konstruksi pada (1) juga menyalahi struktur fungsi yang dimungkinkan dalam kaidah.

\section{Kesalahan Penempatan Konjungtor}

Kesalahan penempatan konjungtor cukup banyak ditemukan dalam novel karya Fiersa Besari (2016). Kesalahan penempatan konjungtor pada bagian ini dibagi menjadi dua jenis, yakni kesalahan penempatan konjungtor yang menyatakan hubungan koordinasi dalam kalimat majemuk setara dan kesalahan penempatan konjungtor yang mengawali sebuah paragraf. Beberapa contoh kalimat yang menyuratkan hal tersebut adalah sebagai berikut. 
(2) ...malam-malamku hanya berisi kumpulan tugas yang harus rela kubagi dengan jam tidur. Dan pagi-pagiku hanyalah repetisi membosankan untuk mengenyangkan logika... (GW, hal. 8)

(3) ...segala keteraturan yang kubangun selama ini runtuh dalam sekejap. Padahal, perjumpaan kita begitu sederhana... (GW, hal. 11)

(4) Namun, nahasnya, sebuah "Hai, apa kabar?" darimu kembali membuyarkan fokusku... (GW, hal. 15)

(5) Dan, aku hanya mampu menjadi korban dari kerinduan yang mencekik... (GW, hal. 16)

(6) Kemudian, pagi kembali berganti malam... (GW, hal. 24)

(7) Padahal, bara membakar hati... (GW, hal. 32)

(8) Tapi, aku mampu mampu untuk memandangimu dari kejauhan tanpa pernah berhenti mendoakan... (GW, hal. 36)

Data (2) dan (3) merupakan kesalahan penempatan konjungtor yang menyatakan hubungan koordinasi dalam kalimat majemuk setara. Secara keseluruhan kalimat di data (2) dan (3) merupakan rangkaian kalimat majemuk setara yang lengkap. Struktur fungsi data (2) adalah konjungsi (dan) + subjek (pagi-pagiku) + predikat (hanyalah repetisi membosankan) + keterangan (untuk mengenyangkan logika). Struktur fungsi data (3) adalah konjungsi (padahal) + subjek (perjumpaan kita) + predikat (begitu sederhana).

Pada data (2) dan (3), konjungtor yang digunakan adalah konjungtor dan dan padahal. Kedua konjungtor tersebut merupakan konjungtor intrakalimat yang menghubungkan kalimat majemuk setara dengan hubungan koordinatif. Namun, penempatan konjungtor koordinatif tersebut berada di setelah tanda titik atau memulai sebuah klausa. Sebagaimana yang telah dibahas pada poin satu, kenyataan ini berkonsekuensi konjungtor yang seharusnya koordinatif dalam kalimat majemuk setara berubah fungsinya menjadi konjungtor antarkalimat.

Di sisi yang lain, kesalahan penempatan konjungtor koordinatif dalam kalimat majemuk menyebabkan klausa yang mendampingi konjungtor menjadi klausa yang tidak berterima karena seluruh fungsi sintaksisnya dikaburkan. Pengaburan fungsi sintaksis yang dimaksudkan di sini adalah fungsi sintaksis yang tidak sempurna sebagaimana seharusnya struktur fungsi yang dimungkinkan. Struktur fungsi yang dimungkinkan dalam sebuah kalimat maksimal adalah $\mathrm{S}+\mathrm{P}+\mathrm{O}+\mathrm{Pel} .+\mathrm{K}$, sedangkan pada data (2) dan (3) terdapat struktur fungsi Konjungtor $+\mathrm{S}+\mathrm{P}+$ dan seterusnya. Kehadiran konjungtor dalam sebuah kalimat sederhana atau simpleks tidak dimungkinkan dalam bahasa Indonesia. Hal tersebut membuat konjungtor kehilangan kodratnya sebagai penghubung dua buah kalimat sederhana dalam sebuah rangkain kalimat majemuk yang utuh.

Data (4) sampai dengan (8) merupakan kesalahan penempatan konjungtor yang mengawali sebuah paragraf. Konjungtor pada data tersebut diletakkan di awal paragraf dalam novel yang bersangkutan. Konjungtor pada data tersebut merupakan konjungtor intrakalimat seperti data (5) sampai dengan (8) dan konjungtor antarkalimat seperti data (4).

Penempatan konjungtor di posisi tersebut merupakan sebuah kekeliruan. Hal ini disebabkan konjungtor yang berada di awal paragraf mengakibatkan sebuah paragraf tidak lagi menjadi sebuah kesatuan ide yang utuh. Konjungtor tersebut berposisi menghubungkan paragraf sebelumnya dengan paragraf yang diawalinya. Paragraf tersebut menjadi sebuah satu-kesatuan ide dari segi makna, tetapi tidak demikian dari segi bentuk karena disebabkan oleh adanya konjungtor yang mengawalinya (bandingkan Kridalaksana, 1985: 87-89).

Selain bukan pada posisinya, konjungtor pada konteks data tersebut juga seharusnya merupakan konjungtor intrakalimat dalam kalimat majemuk setara. Fungsinya bukan menghubungkan dua buah paragraf, melainkan menghubungkan dua buah klausa menjadi sebuah kalimat majemuk setara yang utuh. Kekeliruan semacam ini juga sering terjadi di beberapa tulisan pada kesempatan yang lain.

\section{Kesalahan Tumpang-tindih Antar Konjungtor}

Persoalan tumpang-tindih antarkonjungtor terdapat dalam kalimat majemuk bertingkat yang menggunakan konjungtor subordinatif. Tumpang-tindih antarkonjungtor yang dimaksud di sini adalah hadirnya dua buah konjungtor yang hampir sama fungsinya dalam sebuah rangkaian kalimat. Hal semacam ini termasuk hal yang lewah sebagaimana pada poin satu. Pada bagian ini, hal tersebut digolongkan ke dalam konjungtor yang tumpangtindih, termasuk pada contoh data (1).

(9) ...jika kasmaran adalah narkotik, maka kau adalah bandarnya... (GW, hal. 12)

Konjungtor jika merupakan konjungtor subordinatif yang bermakna syarat dan dapat diubah posisinya dalam kalimat majemuk bertingkat apabila hadir sendiri tanpa kehadiran dengan maka sekaligus. Sebagai misal, pada konstruksi Jika kau adalah bunga, aku adalah tangkainya. Konstruksi kalimat majemuk bertingkat tersebut dapat dibalik konstruksinya menjadi Aku adalah tangkaunya, jika kau adalah bunga. Data (9) memperlihatkan dua buah konjungtor subordinatif yang saling bertumpang-tindih. Kehadiran maka dengan mengemban makna yang hampir sama dalam konteks ini membuat pengubahan posisi data (9) tidak dimungkinkan karena menghasilkan kalimat 
majemuk yang tidak berterima, yakni *maka kau adalah bandarnya jika kasmaran adalah narkotik.

Beberapa contoh data yang sifatnya mewakili pada bagian pembahasan ini merupakan representasi kecil dari berbagai kesalahan yang sering dijumpai pada beberapa sumber lain seperti naskah akademik dan naskah dinas. Konjungtor tidak boleh dianggap sepele dalam penyusunan konstruksi kalimat karena akibat yang timbulkannya menghasilkan kalimat lewah dan tidak berterima. Dengan demikian, kehati-hatian sangat diperlukan dalam menyusun sebuah kalimat, utamanya kalimat majemuk.

\section{TEMUAN DAN HASIL DISKUSI}

Meskipun para ahli telah menerangkan teori dan kaidah mengenai pembagian konjungtor dengan jelas berdasarkan berbagai sudut pandang, pada kenyataannya tetaplah terdapat perbedaan antara teori dan praktik.

Sebagai misal, Alwi dkk. (2003: 402) menyatakan konjungtor namun sebagai bagian dari hubungan perlawanan dalam kalimat majemuk setara. Dengan demikian, konjungtor namun merupakan konjungtor intrakalimat. Sementara itu, pada praktiknya, namun digunakan sebagai konjungtor antarkalimat yang bukan seharusnya demikian (lihat Alwi dkk. 2003: 439). Selain Alwi dkk. (2003), Keraf (2004: 74 dan 138) menggunakan namun dan tetapi sebagai konjungtor yang mengawali paragraf.

Begitu pula dengan perbedaan pendapat antara keberadaan konjungtor antarparagraf. Kridalaksana (1985) mengakui adanya konjungtor antarparagraf, sementara Alwi dkk (2003) tidak menyebut jenis itu dalam klasifikasinya. "Namun", pada praktiknya, Alwi dkk. (2003) menggunakan beberapa konjungtor yang olehnya digolongkan ke dalam konjungtor antarkalimat sebagai konjungtor antarparagraf (lihat Alwi dkk (2003: 439 dan 448 (kasus akan tetapi).

Kenyataan-kenyataan semacam ini perlu mendapat perhatian dan penelitian lebih lanjut sebagai usaha untuk menjelaskan kaidah dengan seterang-terangnya.

\section{E. SIMPULAN DAN SARAN}

Berdasar pada permasalahan yang dibahas pada bagian latar belakang masalah, beberapa hal dapat disimpulkan dalam penelitian ini. Kesalahan penulisan konjungtor dalam novel Garis Waktu: Sebuah Perjalanan Menghapus Luka karya Fiersa Besari (2016) terdiri atas tiga macam. Kesalahan pertama adalah kesalahan penggunaan konjungtor yang berlebihan dalam sebuah konstruksi. Kesalahan kedua adalah kesalahan penempatan posisi konjungtor yang terbagi menjadi dua, yakni kesalahan penempatan konjungtor yang menyatakan hubungan koordinasi dalam kalimat majemuk setara dan kesalahan penempatan konjungtor yang mengawali sebuah paragraf. Kesalahan ketiga adalah tumpang-tindih antarkonjungtor dalam konstruksi kalimat majemuk bertingkat.

Penelitian ini mengambil contoh data pada sebuah novel dengan jumlah data yang terbatas dengan maksud hanya dijadikan contoh kesalahan. Penelitian semacam ini dapat diperluas dengan sumber data yang lebih besar sehingga dapat mengakomodasi data yang lebih bervariasi dan kuantitas lebih banyak. Sumber data dapat berupa tulisan akademik dan naskah dinas agar lebih menyakinkan bahwa kekeliruan sudah sampai pada lingkungan akademik dan kedinasan. Penelitian selanjutnya dapat merealisasikan perihal dimaksud.

\section{UCAPAN TERIMA KASIH}

Ucapan terima kasih kami sampaikan kepada kawankawan UPT MKU Universitas Mataram yang telah memberikan saran dan masukan yang konstruktif atas terlaksananya penelitian ini hingga selesai.

Terima kasih pula kami sampaikan kepada operator OJS FKIP Universitas Muhammadiyah Mataram yang telah melayani koordinasi dengan komunikatif hingga tulisan ini dapat terpublikasikan.

\section{DAFTAR RUJUKAN}

Alwi, Hasan dkk., Tata Bahasa Baku Bahasa Indonesia (Edisi Ketiga). Balai Pustaka, Jakarta, 2003.

Besari, Fiersa, Garis Waktu: Sebuah Perjalanan Menghapus Luka, Media Kita, Jakarta, 2016.

Keraf, Gorys, Tata Bahasa Indonesia, Nusa Indah, Flores, 1987.

Keraf, Gorys, Komposisi, Nusa Indah, Flores, 2004.

Kridalaksana, Harimurti, dkk., 1985. Tata Bahasa Deskriptif Bahasa Indonesia: Sintaksis, Pusat Pembinaan dan Pengembangan Bahasa Departemen Pendidikan dan Kebudayaan, Jakarta, 1985.

Ramlan, M, ilmu bahasa Indonesia Sintaksis, CV Karyono, Yogyakarta, 2005.

Sugihastuti dan Saudah, Siti, Buku Ajar Bahasa Indonesia Akademik, Pustaka Pelajar, Yogyakarta, 2006. 